\title{
Coexistence of RS3PE Syndrome and Ankylosing Spondylitis in a Young Male
}

\author{
Erdem İlgün ${ }^{1}$, Murat Zümrüt ${ }^{2}$, Fethi Demir ${ }^{3}$, Murat Yıldız ${ }^{4}$, Mustafa Keleş ${ }^{4}$ \\ ${ }^{1}$ Private Selçuklu Hospital, Department of Rehabilitation and Physical Therapy, Konya, Turkey \\ ${ }^{2}$ Private Orthopedics and Traumatology Clinic, Konya, Turkey \\ ${ }^{3}$ Private Rehabilitation and Physical Therapy Clinic, Konya, Turkey \\ ${ }^{4}$ Private Internal Medicine Clinic, Konya, Turkey
}

\begin{abstract}
The RS3PE syndrome is the inflammatory rheumatisms of old age, being related to rheumatoid arthritis. Etiology and pathogenesis of this disease is not fully understood and usually seen over 50 years of age and characterized by recurrent symmetrical pitting type edema. We present a case whose clinical symptoms and laboratory findings are compatible with the RS3PE in young male with ankylosing spondylitis. J Clin Exp Invest 2016; 7(4): 290-293
\end{abstract}

Keywords: Ankylosing spondylitis, pitting edema, symmetric synovitis.

\section{GiRiş}

Seronegatif romatoid artritin bir alt grubu olan remittan seronegatif simetrik sinovit ve pitting ödem (RS3PE) 1985’te Mc Carty ve arkadaşları tarafından tanımlanmıştır [1]. RS3PE el ve ayaklarda simetrik sinovit, tenosinovit ve ödemle karakterize bir sendromdur. Kortikosteroide çok iyi yanıt veren bu hastalık, dominant olarak erkek ve yaşılıarda görülür [2]. Etyopatogenezi tam olarak bilinmemekle birlikte tipik olarak romatoid faktör (RF) negatiftir. HLA B7 ve HLA B27 ile ilişkisi henüz tam kanıtlanmış olmasa da bazı çalışmalarda bu markerların pozitifliği bulunmuştur $[3,4,5]$. Ayrıca hafif orta şiddette bir akut faz yanıtı mevcudiyeti söz konusu iken anti nükleer antikor (ANA) negatiftir [5]. Bunun aksine Olive ve ark. düşük titre ANA pozitifliği bildirmiş ve hastalığı 50 yaşın üzerinde, her iki el dorsalinde gode bırakan ödem, ani başlangıçlı poliartrit ve RF negatifliğiyle giden bir patoloji olarak tariflemiştir(6). RS3PE sıklıkla 50 yaş üzerinde ve erkelerde görülmesine karşın bizim olgumuz 28 yaşında ankilozan spondilitli (AS) erkek bir hastaydı. Amacımız literatürde belirtilenden farklı olarak AS nedeniyle takip edilen genç bir hastada RS3PE varlığını sunmaktır.

\section{OLGU}

Yirmi sekiz yaşında erkek hasta polikliniğimize 2 gündür her iki el bileğinde özelliklede sağ el bilek ve sağ el dorsalinde ani gelişen ağrı ve şişlik şikayetiyle başvurdu. Öyküsünde travma, herhangi bir böcek sokması, anjio ödem ve ürtiker gibi ani şişlik yapabilecek bir durum yoktu. Hikayesinde Reynaud fenomeni, ağız kurluğu, oral aft, genital aft, ciltte döküntüler, kuru göz, kelebek tarzı döküntüler, yutma güçlüğü yoktu. Özgeçmişinde 6 yıl önce AS tanısı konulup tedavi başlandığı öğrenildi. Özellikle sabahları bel ve sırt ağrılarının ve dönem dönem yer değiştiren kalça ağrısının olduğunu ifade eden hastanın yaklaşık bir saati geçen sabah tutuklukları oluyormuş.

Hastanın sistemik muayenesinde tansiyon arteryel: $128 / 80 \mathrm{mmHg}$, nabız sayısı: 76/dakika, ateş: $37,2^{\circ} \mathrm{C}$ idi. Kas iskelet sistemi muayenesinde; her iki el- el bileğinde özelliklede sağ el bileğinde diffüz şişlik mevcuttu. Palpasyonda her iki el-el bilek dorsalinde gode bırakan ödem ve minimal ısı artışı tesbit edildi. 
Tinnel ve phalen testleri negatifti. Nörolojik defisit yoktu. Sağ el-el bileği hariç diğer eklemlerde aktif artrit yoktu. Bel eklem hareket açıkığı fleksiyonda kısıtı ve ağrılı, el zemin mesafesi $19 \mathrm{~cm}$, schöber $14 \mathrm{~cm}$, modifiye schöber $18 \mathrm{~cm}$, tragus duvar mesafesi $17 \mathrm{~cm}$, lateral fleksiyonlar $3.5 \mathrm{~cm}$, göğüs expansiyonu 5 $\mathrm{cm}$ olarak ölçüldü. FABER, FADIR açık ağrılı, sakroilaik kompresyon testi sağda hafif pozitifti. Mennel testi negatif olarak değerlendirildi. Laboratuvar incelemede beyaz küre, hemoglobin, platelet değerleri norma liken; eritrosit sedimantasyon hız: $45 \mathrm{~mm} / \mathrm{saat}$, romatoid faktör (RF): $8(<20) \mathrm{IU} / \mathrm{ml}$, C-reaktif protein (CRP): $6,82(0,01-0,82) \mathrm{mg} / \mathrm{l}$, ürik asit $6.7 \mathrm{mg} / \mathrm{dl}, \mathrm{Ca}: 10,1 \mathrm{mg} / \mathrm{dl}$, CK:186 U/L, ANA, anti-dsDNA ve c-ANCA ise negatifti. Tam idrar tetkiki, serum elektrolitleri, SGOT, SGPT, TSH testleri normal olarak saptandı. Hastanın sakroiliak MR filminde bilateral sakroileit bulgusu mevcuttu. Çekilen ön-arka el-el bileği grafisi normal olarak değerlendirildi. Hastanın sistemik muayenesinde patolojik bulgu yoktu. Hastada bu bulgularla RS3PE ön tanıSı düşünülerek 10 mg/gün prednizolon ve klorokin tedavisi başlandı. Hastanın 4 gün sonraki kontrolünde kliniğinin dramatik bir şekilde düzeldiği görüldü..

\section{TARTIŞMA}

Illk kez McCarty tarafından tarif edilen RS3PE; genellikle 50 yaş üzeri erkeklerde, ani başlangıçlı, ellerde ve ayaklarda gode bırakan ödem ve simetrik artrit yapan, yüksek eritrosit sedimantasyon hızı ve genellikle RF negatifliğiyle seyreden, yaklaşık 18 ay civarı remisyona giren, noneroziv, düşük doz steroide çok iyi cevap veren bir sendromdur [1,7]. Laboratuvar bulgularında RF negatifliğine ek olarak ANA negatif olup, bazı hastalarda HLAB7 (8), HLA B22 antijenleri pozitif bulunmuştur $[5,9]$. Bizim olgumuz erkek olması, RF negatifliği, ellerde bilateral pitting ödem varlığı, ani başlangıçlı olması, HLA B27 pozitifliği, eritrosit sedimantasyon hızının yüksekliği $(45 \mathrm{~mm} / \mathrm{saat})$ ile benzer klinik ve laboratuvar bulgularına sahipken; genç yaşta olması literatürde bildirilen ileri yaş kriterine uymuyordu. Hastamızın AS nedeniyle 5 yıldır tedavi alıyor olması ve AS nin tipik olarak genç erkek hastalarda görülmesi ve gerek AS'nin gerekse RS3PE'nin etiopatogenezinde HLA B27 pozitifliğiyle ilişkisi hastamızın erken yaş kriterini destekleyebilir.

RS3PE de gözlenen simetrik sinovit ve şişlik, en sık elbileği ve ayak bileklerindedir. Gode bırakan ödem karakteristik bir bulgudur. Gode bırakan ödemin ayırıcı tanısında simetrik ve non simetrik artrit yapan romatizmal hastalıklar, geç başlangıçlı romatoid artrit (RA) [10), geç başlangıçlı periferik spondiloartropati [11], bağ doku hastalıkları, miks konnektif doku hastalıkları [12), tiroid, karaciğer, böbrek hastalıkları, konjestif kalp yetmezliği, lenfatik obstrüksiyon gibi çok geniş bir hastalık grubunun göz önünde bulundurulması gerekir [13]. RS3PE'deki ödem lenf ödemden tamamen farklıdır; pürüssüz gode bırakan ödem tarzındadır ve steroid tedavisiyle hızlı bir şekilde iyileşir [14]. Hastamız multidisipliner olarak değerlendirildiğinde ayrıcı tanıda gode bırakan ödem sebeplerini düşündürecek bir patoloji saptanmadı.

RS3PE olgularının çoğu idiopatik olarak tespit edilmesine rağmen benign ve malign birçok hastalık RS3PE olgularına eşlik edebilir; gut, pseudogut, kompleks bölgesel ağrı sendromu ve karpal-tarsal tünel sendromu [15], sjögren sendromu [16], Polimiyaljia Romatika (PMR) [17], RA, sarkoidoz gibi hastalıklar ayırıcı tanıda mutlaka göz önünde bulundurulmalıdır. RS3PE sendromlu hastaların bir kısmında RA, AS ve konnektif doku hastalıkları [13], PMR [17] gibi romatizmal hastalıklar gelişebileceğini ifade eden yayınlar varken; başka bir görüş olarak bu sendromun, diğer romatolojik hastalıklarla ilişkili bir hastalık olup olmadığı veya romatolojik hastalıkların bir başlangıç formu mu olduğu net değildir (18). Bizim vakamızda hasta AS nedeniyle takip edilmekteydi. AS'nin gode bırkan ödem yaptığına dair literatürde bir bulguya rastlamadık. Hastanın klinik ve laboratuvar bulguları değerlendirildiğinde ayırıcı tanıda göz önünde bulundurulması gereken RA, sarkoidoz, PMR, SLE gibi romtolojik hastalıklar düşünülmedi.

RS3PE etyopatogenezinde de AS patogenezinde etkisi kanıtlanmış HLA B27'nin sorumlu olabileceğine dair çalışmalar mevcuttur. Schaeverbeke et al. RS3PE li 22 hasta üzerinde yaptıkları bir çalışmada 7 hastada HLA B27 pozitifliği tesbit etmişler [13]. Finnel ve ark. RS3PE sendromlu olan hastaların yaklaşık\% 
50'sinde HLA-B27 fenotipini pozitif olarak bildirmişler [16]. Bizim olgumuz 5 yıldır AS tedavisi almaktaydı ve HLAB27 pozitifti.

Eklemlerde radyolojik olarak eroziv ve dejeneratif değişikliklerin gözlenmemesi [8] ve düşük doz kortikosteroide iyi yanıt hastalığın karekteristik özelliklerindendir [19]. RS3PE sendromunda, prognozun genel olarak son derece iyi olduğu kabul edilmesine rağmen bazı maligniteler gelişmesi kareketeristik bir özelliğidir. RS3PE sendromuyla bağlantılı olarak hematolojik (lösemi, lenfoma), myelodisplastik sendrom [6] ve gastrik, pankreas kanseri gibi maligniteler gelişebilmektedir [20). Bizim olgumuz steroide çok dramatik bir yanıt verdi ve kliniğinde malignite bulgusuna rastlanmadı.

Khan RS3PE sendromunu, seronegatiflerin tanı kriterlerini tam olarak doldurmamasına rağmen AS gibi bu grubta değerlendirmiştir[21]. Seronegatif spondiloartropatilerin prototipi olan AS, kronik, inflamatuvar, progresif bir hastalıktır. Sakroiliyak eklem tutulumunun ön planda olduğu hastalığın geç dönemlerinde aksiyal ve periferik eklem tutulumu da gözlenir. Ekstra artiküler olarak göz, kalp, akciğer ve bağırsak gibi organlar tutulur. HLA-B27 geni yaklaşık \%95 oranında pozitiftir. 17-35 yaş arasında, sıklıkla genç erkeklerde, sinsi başlangıçlı olarak karşımıza çıkar [22]. Hastalığın başlama yaşı, ergenlikten genç erişkin yaşa kadar değişkenlik gösterebilir ve yaklaşık 28 yaşlarında doruk sıklığa ulaşır. Hastalığın seyrinde. periferal eklem tutulumu daha az olmasına karşın kalça ve omuz eklemleri olguların üçte birinde tutulur. El-elbileğinde bilateral ya da asimetrik bulgular ön plandadır. Distal interfalangeal, proksimal interfalangeal, metakarpofalangeal eklemlerin yanı sıra birinci parmak interfalangeal eklemide tutabilir [23]. Literatürde $\mathrm{AS}^{\prime}$ nin eklem tutulumunda gode bırakan ödem bulgusuna dair bir bilgiye rastlamadık.

Sonuç olarak, literatürde daha çok ileri yaşlarda görülen RS3PE sendromu HLA B27 pozitifliğiyle giden AS'li hastalarda daha erken yaşlarda görülebileceği akılda tutulmalıdır.

Conflict of Interest: The authors declare no conflict of interest.

\section{KAYNAKLAR}

1. McCarty DJ, O'Duffy JD, Pearson L, Hunter JB. Remitting seronegative symmetrical synovitis with pitting edema. J Am Med Assoc 1985; 54:2763-2767.

2. Sayarlıoğlu M. Europ J Gen Med 2004;1: 3-5.

3. Chaouat D, Périer JY, Le Parc JM, Belange G. Subacute oedem atou spondyloarthritis of the elderly. Presse Med 1990; 19:1705-1708.

4. Bhakta BB, Pease CT. Late-onset rheumatoid arthritis: is pitting oedema of the hands at onset a good prognostic indicator? $\mathrm{Br} J$ Rheumatol. 1997; 36:214-219.

5. Roblot $P$, Zaim A, Azais I, Ramassamy A, Paccalin M, Becq-Giraudon B. RS3PE: A clinical diagnosis, a prognosis more simple than its name. Rev Med Intern 1998; 19:542-547.

6. Olive A, del Blanco J, Pons M, Vaquero M, Tena $X$. The clinical spectrum of remitting seronegative symmetrical synovitis with pitting edema. J Rheumatol 1997;24:333-336.

7. Olivieri I, Salvarani C, Cantini F. RS3PE syndrome: an overview. Clin Exp Rheumatol 2000; 18: $53-55$

8. Russell EB, Hunter JB, Pearson L, McCarty DJ. Remitting, seronegative, symmetrical synovitis with pitting edema 13 additional cases. J Rheumatol 1990; 17:633-639.

9. Şendur OF, Ozer H, Tureli C. RS3PE: Bir olgu sunumu. Turk Fiz Tıp Rehab Derg 1999; 3:8-16.

10. Chaouat D, Le Parc J M. The syndrome of seronegative symmetrical synovitis with pittingedema (RS3PE Syndrome): a unique form of arthritis in the elderly? Report of 4 additiona Icases. Rheumatol 1989; 16: 1211-1213.

11. Olivieri I, Oranges GS, Sconosciuto F, Padula A, Ruju GP, Pasero G. Late onset peripheral seronegative spondyloarthropathy: report of two additional cases. J Rheumatol 1993; 20: 390-393.

12. Leroy EC, Maricq HR, Kahaleh MB. Undifferentiated connective tissue syndromes. Arthritis Rheum 1980; 23:341-343.

13. Schaeverbeke $T$, Fatout $E$, Marce $S$, et al. Remitting seronegative symmetrical synovitis with pitting oedema: disease or syndrome? Ann Rheum Dis 1995; 54: 681-684.

14. Jayson MI, Barks JS. Oedema in rheumatoid arthritis: changes in the coefficient of capillary filtration. BMJ 1971; ii: 555-557.

15. Yalbuzdag $S A$, Sarıfakıŏlu $A B$, Karataş $M$. Unilateral RS3PE Syndrome. Turk J Rheumatol 2013; 28:141-142.

16. Finnell JA, Cuesta IA. Remitting seronegative symmetrical synovitis with pitting edema (RS3PE) 
syndrome: a review of the literature and a eport of three cases. J Foot Ankle Surg 2000; 39(3): 189-193.

17. Salvarani C, Gabriel S, Hunder GG. Distal extremity swelling with pitting edema in polymyalgia rheumatica. Report on 19 cases. Arthritis Rheum 1996; 39: 73-80.

18. Medrano San Ildefonso M, MauriLlerda JA. Remitting seronegative symmetrical synovitis with pitting edema (RS3PE): a paraneoplastic syndrome? A new case. Clin Exp Rheumatol 2007; 25:342.

19. Yao $Q$, Su X, Altman RD. Is remitting seronegative symmetrical synovitis with pitting edema (RS3PE) a subset of rheumatoid arthritis? Semin Arthritis Rheum. 2010; 40(1):89-94.

20. Paksoy F, Ulaş T, Mazı EE, Damar AB, Borlu F. Syndrome of Remitting Seronegative Symmetrical Synovitis with Pitting Edema (RS3PE). Turk J Rheumatol 2010; 25: 88-90.

21. Khan MA: Diagnosis of spondyloarthropathies. Romatol Tib Rehab 1997; 8(2): 97-99.

22. Çağlar NS, Burnaz Ö, Akın T, Özgönenel L, Çetin $E$, et al. Demographic and clinical properties and medical treatments of patients followed as ankylosing spondylitis. Istanbul Med J 2011; 12(1):19-24.

23. Örgüç Ş. Romatolojik hastalıklarda üst ekstremite tutulumu. Trd Sem 2014; 2: 103-117. 